\title{
How dynamic are ice-stream beds?
}

\author{
Damon Davies ${ }^{1}$, Robert G. Bingham ${ }^{1}$, Edward C. King ${ }^{2}$, Andrew M. Smith ${ }^{2}$, Alex M. Brisbourne ${ }^{2}$, Matteo Spagnolo ${ }^{3}$, \\ Alastair G. C. Graham ${ }^{4}$, Anna E. Hogg ${ }^{5}$, and David G. Vaughan ${ }^{2}$ \\ ${ }^{1}$ School of GeoSciences, University of Edinburgh, Edinburgh, EH8 9XP, UK \\ ${ }^{2}$ NERC British Antarctic Survey, Cambridge, CB3 OET, UK \\ ${ }^{3}$ School of Geosciences, University of Aberdeen, Aberdeen, AB24 3UF, UK \\ ${ }^{4}$ College of Life and Environmental Sciences, University of Exeter, Exeter, EX4 4RJ, UK \\ ${ }^{5}$ Centre for Polar Observation and Modelling, School of Earth and Environment, University of Leeds, Leeds, LS2 9JT, UK
}

Correspondence: Robert G. Bingham (r.bingham@ed.ac.uk)

Received: 27 September 2017 - Discussion started: 13 October 2017

Revised: 8 March 2018 - Accepted: 12 March 2018 - Published: 4 May 2018

\begin{abstract}
Projections of sea-level rise contributions from West Antarctica's dynamically thinning ice streams contain high uncertainty because some of the key processes involved are extremely challenging to observe. An especially poorly observed parameter is sub-decadal stability of ice-stream beds, which may be important for subglacial traction, till continuity and landform development. Only two previous studies have made repeated geophysical measurements of ice-stream beds at the same locations in different years, but both studies were limited in spatial extent. Here, we present the results from repeat radar measurements of the bed of Pine Island Glacier, West Antarctica, conducted 3-6 years apart, along a cumulative $\sim 60 \mathrm{~km}$ of profiles. Analysis of the correlation of bed picks between repeat surveys shows that $90 \%$ of the bed displays no significant change despite the glacier increasing in speed by up to $40 \%$ over the last decade. We attribute the negligible detection of morphological change at the bed of Pine Island Glacier to the ubiquitous presence of a deforming till layer, wherein sediment transport is in steady state, such that sediment is transported along the basal interface without inducing morphological change to the radarsounded basal interface. Given the precision of our measurements, the upper limit of subglacial erosion observed here is $500 \mathrm{~mm} \mathrm{a}^{-1}$, far exceeding erosion rates reported for glacial settings from proglacial sediment yields, but substantially below subglacial erosion rates of $1.0 \mathrm{~m} \mathrm{a}^{-1}$ previously reported from repeat geophysical surveys in West Antarctica.
\end{abstract}

\section{Introduction}

Glaciological studies over the past three decades have revealed that the West Antarctic Ice Sheet (WAIS) is losing mass at an accelerating rate, raising concerns over its potential future contribution to global sea level (Shepherd et al., 2012; DeConto and Pollard, 2016). Between 2010 and 2013, around $33 \%$ of the ice sheet's net mass loss came from Pine Island Glacier (hereafter PIG), a major ice stream draining to the Amundsen Sea Embayment (McMillan et al., 2014). There, from satellite altimetry observations, mass loss was first expressed at the grounding zone in the mid-1990s, and has now propagated all the way up to the divides (McMillan et al., 2014) by a set of processes broadly termed dynamic thinning (Shepherd et al., 2001; Pritchard et al., 2009). At PIG the dynamic thinning has incorporated an upstream expansion of regions both of accelerating ice (e.g. Scott et al., 2009; Mouginot et al., 2014) and ice-surface lowering (e.g. Konrad et al., 2017), and upstream migration, by several 10s of km, of the grounding line (e.g. Park et al., 2013; Rignot et al., 2014), prompting suggestions that PIG is in runaway retreat (Joughin et al., 2014). However, the detailed processes by which dynamic thinning works, especially upstream from the grounding zone, are not well constrained. Particularly unclear is how the coupling between basal ice and the bed may evolve or vary over time and whether this needs to be accounted for in models projecting future ice response. For example, previous studies have theorised that high subglacial till fluxes can lead to the rapid formation of grounding-zone 
wedges, potentially stabilising ice streams against sea-level rise (e.g. Alley et al., 1989, 2003; Alley et al., 2007).

Monitoring the beds of ice streams is also important for understanding processes of erosion and sediment transport that can provide information on landscape evolution (e.g. Jamieson et al., 2010; Herman et al., 2011), basal processes (Cuffey and Alley, 1996; Alley et al., 1997; Alley, 2000) and the supply of nutrients to polar oceans (Raiswell et al., 2006). Furthermore, knowledge of till flux and associated till properties is key to an improved understanding of glacier physics and ice-stream stability (Blankenship et al., 1986; Boulton and Hindmarsh, 1987; Alley, 1989; Jenson et al., 1995; Engelhardt and Kamb, 1998; Truffer et al., 2000; Iverson and Iverson, 2001; Nygård et al., 2007; Damsgaard et al., 201, 2016). A review of previously published erosion rates for hard-bedded glaciers (Hallet et al., 1996) indicates low erosion rates in polar settings $\left(0.01 \mathrm{~mm} \mathrm{a}^{-1}\right)$ contrasting with relatively high rates beneath temperate alpine glaciers $\left(10-100 \mathrm{~mm} \mathrm{a}^{-1}\right)$. However, more recent studies have identified far more rapid erosion rates of $4.8 \mathrm{~mm} \mathrm{a}^{-1}$ in Greenland (Cowton et al., 2012) and as much as $1 \mathrm{~m} \mathrm{a}^{-1}$ or more in softbedded glaciers in Alaska (Motyka et al., 2006) and Antarctica (Smith et al., 2007; 2012). Critically, measurements of erosion rates in Antarctica are limited both temporally and spatially, making it difficult to assess whether such high rates of erosion are typical or exceptional.

A significant difficulty in assessing temporal changes to the beds of WAIS ice streams is lack of direct access. Theoretical and geophysical constraints have shown that ice streams typically achieve fast flow by overriding dilated till that provides low basal drag (Alley et al., 1986; Bentley et al., 1998). It has been inferred that even relatively small fluctuations to hydrological conditions in these locations can induce significant changes to basal drag, in the most extreme circumstances causing ice streams to switch on or off (e.g. Anandakrishnan and Alley, 1997; Conway et al., 2002; Vaughan et al., 2008). However, to our knowledge, only two studies have attempted directly to capture temporal changes to ice-stream bed conditions over decadal to sub-decadal timescales commensurate with available satellite records of surface elevation and velocity change. The first was a singlelocation repeat measurement of ice thickness and surface elevation on PIG (location, Fig. 1) made firstly in 1960 and remeasured in 2009 (Smith et al., 2012). That study found surface lowering with no significant change in ice thickness, suggesting that mean erosion of the ice-stream bed of up to $1 \mathrm{~m} \mathrm{a}^{-1}$ took place during the study period (Smith et al., 2012). This rate is well above the range reported elsewhere (Hallet et al., 1996). The second, more detailed study, consisted of three repeat seismic surveys of the bed of Rutford Ice Stream (hereafter RIS; Fig. 1c) obtained in 1991, 1997 and 2004 (Smith et al., 2007). There, across a $\sim 0.5 \mathrm{~km}$ width of the bed, $6 \mathrm{~m}$ of sediment were removed from the ice bed between 1991 and 1997 followed by the appearance of a drumlin $10 \mathrm{~m}$ high and $100 \mathrm{~m}$ wide between 1997 and
2004. Both of the studies from West Antarctica therefore implied that active sediment erosion or deposition at rates $\sim 1-$ $1.4 \mathrm{~m} \mathrm{a}^{-1}$, and landform evolution, are possible beneath ice streams on decadal to sub-decadal timescales.

In this paper, we present and analyse results from three repeat surveys of the bed of PIG, whereby we geophysically surveyed co-located profiles of PIG's bed in different years along a cumulative $\sim 60 \mathrm{~km}$ of traverses. Our principal aim was to ascertain whether erosion or deposition, and any morphological changes, were detectable at the bed of PIG over intervals of 3-7 years, periods over which PIG (from satellite monitoring) has undergone considerable ice-surface lowering and ice acceleration (McMillan et al., 2014; Mouginot et al., 2014).

\section{Methods}

Our data consist of three repeat radar surveys of PIG's bed acquired with a low frequency ice-penetrating radar system in austral seasons 2007/2008 and 2013/2014 (two profiles of 18 and $16 \mathrm{~km}$ long separated by $\sim 6$ years) and 2010/2011 and 2013/2014 (one $25 \mathrm{~km}$ profile separated by $\sim 3$ years) (Fig. 1a, b). The $18 \mathrm{~km}$ profile, R1, was acquired $3 \mathrm{~km}$ downstream and parallel to an $18 \mathrm{~km}$ seismic survey acquired in austral season 2007/2008 (Smith et al., 2013), $5 \mathrm{~km}$ of which was resurveyed in austral season 2014/2015 (Brisbourne et al., 2017) (profiles $\mathrm{S1}_{2007}$ and $\mathrm{S1}_{2014}$ on Fig. $1 \mathrm{~b}$ respectively). Each of the repeat survey locations on PIG experienced significant ice-surface lowering and acceleration over the encompassing period (Table 1). In our analysis we consider our findings from PIG against the results from Smith et al.'s (2007) repeat seismic surveys of the bed of RIS (profile $\mathrm{C} 1$ in Fig. 1c), where ice flow has remained relatively stable over decadal timescales and negligible surface lowering has been observed (Table 1).

\subsection{Data acquisition}

All radar profiles were acquired with the British Antarctic Survey's "DELORES" (Deep-Look Radio-Echo Sounder) system, a skidoo-towed monopulse array (see King et al., 2016, for general specifications). During the 2007/2008 field season, the system operated using $40 \mathrm{~m}$ half-dipole antennae, resulting in a centre frequency of 1.2 MHz. In 2010/2011 and 2013/2014, $20 \mathrm{~m}$ half-dipole antennae were used, giving a centre frequency of $3 \mathrm{MHz}$. Along-track traces were sampled at $<1 \mathrm{~m}$ intervals, stacked for noise reduction to produce data points at $\sim 5 \mathrm{~m}$ spacing, and georeferenced with a dual-frequency differential GPS mounted on the radar system.

The repeat radar surveys on PIG were each acquired approximately orthogonal to ice flow at sites 150, 120 and $115 \mathrm{~km}$ upstream from the 2011 grounding line (Park et al., 2013) (R1, R2 and R3 respectively in Fig. 1b), in each case 

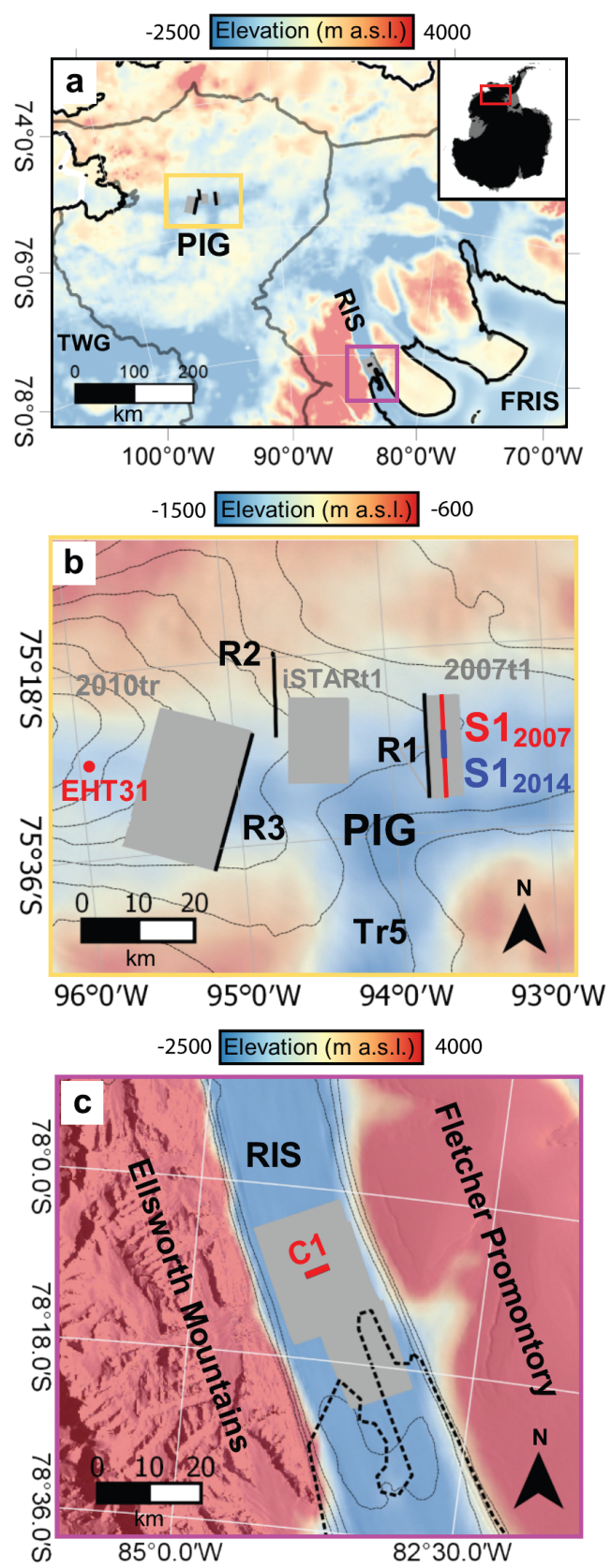

Figure 1. Location maps of the study area. Colour scale shows BEDMAP2 bed elevation (Fretwell et al., 2013). (a) Map of the Pine Island Glacier (PIG) and Rutford Ice Stream (RIS) catchments. Grey lines show drainage boundaries (Zwally et al., 2012). (b) Location of PIG surveys. Grey contours are $100 \mathrm{~m} \mathrm{a}^{-1}$ ice surface velocity contours (Rignot et al., 2011). Grey shaded boxes show the locations of radar grid DEMs in Figs. 2a, 3a and 3f, black lines are repeat radar surveys. $\mathrm{S}_{2} 2007$ is a seismic survey presented in Smith et al. (2013) and $\mathrm{S}_{2014}$ is a section of this profile resurveyed in 2014 (presented in Brisbourne et al., 2017). EHT31 is a single point repeat survey presented in Smith et al. (2012). (c) Location of RIS surveys. Thick dashed line represents the MODIS grounding line. Grey contours are $100 \mathrm{~m} \mathrm{a}^{-1}$ velocity contours (Rignot et al., 2011). Grey shaded box is the area of the radar grid DEM in Fig. 5a. close to, or forming part of, more extensive radar surveys of patches of the ice bed conducted in the three field seasons (Bingham et al., 2017). Repeat radar profile R1 comprises a traverse $\sim 18 \mathrm{~km}$ in length, first surveyed in January 2008 and then again in December 2013. The January 2008 profile also represents the most downstream traverse of a more extensive set of radar profiles used to image a $108 \mathrm{~km}^{2}$ patch of PIG's bed in January 2008 surrounding the $18 \mathrm{~km}$ seismic profile acquired in the same season (patch 2007t1 and seismic profile $\mathrm{S}_{2007}$ in Fig. 1b). Profile R2 is derived from a $16 \mathrm{~km}$ traverse first driven in December 2007 and then again in December 2013; this profile lies $\sim 2 \mathrm{~km}$ downstream of an extensive survey of $150 \mathrm{~km}^{2}$ of PIG's bed also surveyed in December 2013 (patch iSTARt1 in Fig. 1b). Profile $\mathrm{R} 3, \sim 25 \mathrm{~km}$ in length, was first surveyed in January 2011 as the upstream profile of multiple transects used to image a $425 \mathrm{~km}^{2}$ patch of PIG's bed (patch 2010tr in Fig. 1b), and then again in December 2013 to yield a survey gap of $\sim 3$ years.

\subsection{Data processing}

Radar data were processed using ReflexW seismic processing software (Sandmeier Scientific Software). A data processing flow was applied which included a gain function to improve the strength of reflections at greater depth, and bandpass and 2-D median filters to reduce data noise. Finitedifference (FD) migration was used to contract diffraction hyperbolae and to recover the correct locations of individual reflectors. The onset time of the bed reflector was determined at $5 \mathrm{~m}$ horizontal intervals at the peak in the amplitude of the bed reflector using a semi-automated "phase follower" picking procedure that allows automatic assignment of picks to a selected phase. These picks were checked and edited using manual picking where necessary. Bed picks were then converted to depth using a radar wave speed of $0.168 \mathrm{~m} \mathrm{~ns}^{-1}$ and no additional firn correction. We smoothed bed picks by applying a moving average over a $50 \mathrm{~m}$ window to all bed picks to remove high-frequency noise.

To assess changes at the bed, we focus on comparing the morphological character of the picked bed along repeat profiles rather than deriving changes in absolute bed elevation between surveys. This is for two reasons. Firstly, we do not have the data to assess whether firn properties, that impact upon radar wave speed, changed over the periods between repeat surveys. However we do not expect firn properties to have varied spatially on the scale of our surveys. For this reason we make no firn correction to our derived ice thicknesses. Secondly, differences in the triggering mechanism of the radar system between survey years meant that we could not directly match the onset waveforms between repeat surveys. In both cases, the effects preclude recovery of absolute ice thickness or bed elevation. Therefore we compare relative bed profiles by applying a static correction to a common bed datum $(0 \mathrm{~m})$ for both surveys. 
Table 1. Mean velocities and surface elevation change for each repeat radar survey profile 2007-2017.

\begin{tabular}{lrrrr}
\hline Survey & $\begin{array}{r}\text { Velocity }\left(\mathrm{m} \mathrm{a}^{-1}\right) \\
2007-2009 \\
(\text { MEaSUREs })\end{array}$ & $\begin{array}{r}\text { Velocity } \\
\left(\mathrm{m} \mathrm{a}^{-1}\right) \\
2017^{\mathrm{a}}\end{array}$ & $\begin{array}{r}\text { Velocity change } \\
\left(\mathrm{m} \mathrm{a}^{-1}\right)\end{array}$ & $\begin{array}{r}\text { Mean surface } \\
\text { elevation change } \\
(\mathrm{m})^{\mathrm{b}}\end{array}$ \\
\hline C1 (RIS) & 370 & 407 & 37 & - \\
R1 (PIG) & 287 & 361 & 74 & -8.2 \\
R2 (PIG) & 384 & 523 & 139 & -8.0 \\
R3 (PIG) & 435 & 609 & 174 & - \\
\hline
\end{tabular}

a Velocities derived from Sentinel-1 image pairs obtained in April 2017. Details of processing methodology are provided in Hogg et al. (2017). ${ }^{\mathrm{b}}$ Surface elevation change derived from differential GPS measurements. No GPS data were available for surveys $\mathrm{C} 1$ and $\mathrm{R} 3$.

The seismic surveys $\mathrm{S}_{2007}$ and $\mathrm{S1}_{2014}$ in the vicinity of R1 were processed and analysed by Smith et al. (2013; 2007/2008 profile only) and Brisbourne et al. (2017; both profiles). Brisbourne et al. (2017) primarily report on the calculation of acoustic impedance at the bed from both profiles, which we will consider in our discussion below. For this paper, we also investigated the possibility of directly picking the bed for the repeated $5 \mathrm{~km}$ section in an analogous manner to the radar picking described above. However, low signal-noise ratios along large parts of the bed, resulting from the similarity of ice and bed acoustic impedance (Brisbourne et al., 2017), precluded the recovery of results with sufficiently low picking errors to have confidence in identifying any change or lack thereof.

\subsection{Errors}

For each profile R1-R3, the ability to detect changes in bed morphology is largely determined by the precision with which the bed reflector can be picked, and the degree to which the second radar profile of a repeat survey follows or diverges slightly from the path driven by the first profile.

The signal-to-noise ratio in all our radar profiles is high and the strength of the basal reflector produces a clearly discernible, high-amplitude wavelet (e.g. radargrams in Figs. 25) that requires little user interaction during the semiautomatic picking procedure. With such clear data, the uncertainty with which the bed reflection can be picked is determined primarily by the system rise-time of $250 \mathrm{~V} \mathrm{~ns}^{-1}$, the recording-system bandwidth of $50 \mathrm{MHz}$ and the digitisation interval of $10 \mathrm{~ns}$. Also, considering the uncertainty in our GPS-derived elevations, we estimate that our radar data have a vertical range precision of $\pm 3 \mathrm{~m}$.

As we are unable to recover absolute elevation change, in this study the horizontal resolution is more important than the vertical range precision. Differences in the morphology of the basal reflector need to be considered along with consideration of the different frequencies used in repeat surveys (1.2 and $3 \mathrm{MHz})$. This is best illustrated using commonly adopted resolution limits. For a circular wavefront, features at the bed with a width less than $\sqrt{2 d \lambda+\frac{\lambda^{2}}{4}}$ will
Table 2. Analysis of navigational divergence and associated variability in bed elevation.

\begin{tabular}{lrrr}
\hline Repeat survey line & $\mathrm{R} 1$ & $\mathrm{R} 2$ & $\mathrm{R} 3$ \\
\hline Repeat survey divergence $(\mathrm{m})$ & & & \\
\hline Maximum & 45.1 & 54.0 & 35.0 \\
Mean & 23.7 & 13.7 & 20.0 \\
Standard deviation & \pm 10.3 & \pm 12.0 & \pm 8.0 \\
\hline
\end{tabular}

appear as point diffractors. For a bed at a depth of $2000 \mathrm{~m}$, a $1.2 \mathrm{MHz}\left(\lambda_{\text {ice }}=250 \mathrm{~m}\right)$ wavelet will image features with a width $<1008 \mathrm{~m}$ and a $3 \mathrm{MHz}\left(\lambda_{\text {ice }}=100 \mathrm{~m}\right)$ wavelet will image features with a width $<634 \mathrm{~m}$. These differences may affect the appearance of the basal reflector depending on the roughness of the bed. For these reasons we express caution when considering subtle changes in basal morphology.

Survey lines were repeated by following a route programmed into a dashboard GPS unit mounted on the radar skidoo. Due to the higher accuracy and precision of the dual-frequency GPS compared to the dashboard units, and the challenges of navigating in featureless terrain, navigational divergences were registered. These divergences were mostly $<50 \mathrm{~m}$ (Table 2); however, where bed topography is rough, even small navigational divergences may lead to incorrect interpretation of bed change. In order to visually assess whether navigational divergence affects observed bed change we have provided plots of minimum horizontal distance between repeat surveys alongside bed elevation profiles in Figs. 2 and 3.

\section{Results}

Bed picks for the repeat geophysical surveys from PIG are shown in Figs. 2 and 3 alongside associated geophysical images. A visual inspection of the radar/seismic images and bed picks (Figs. 2 and 3) shows that there is remarkable consistency in the morphology of the bed at all three of the repeat survey sites. This qualitative impression is confirmed by calculating the Pearson correlation coefficient $(r)$ of each repeat 


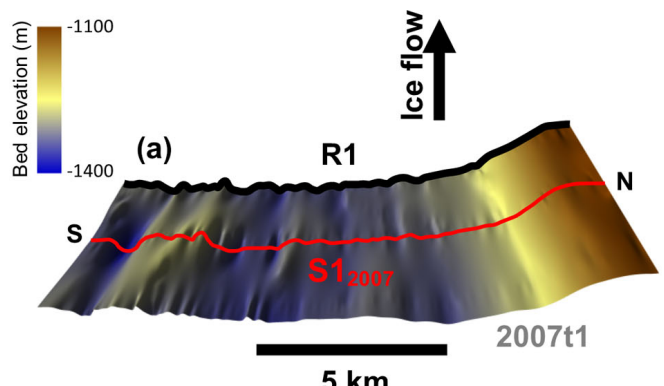

(b)

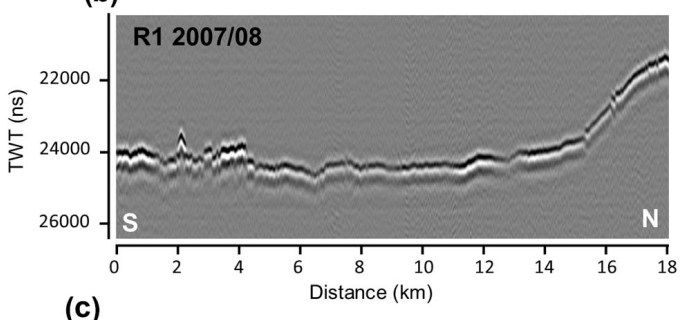

(c)

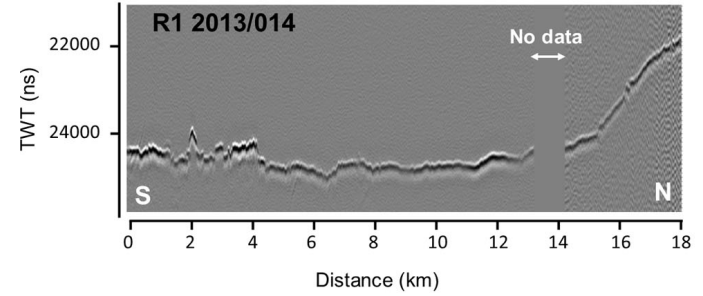

(d)

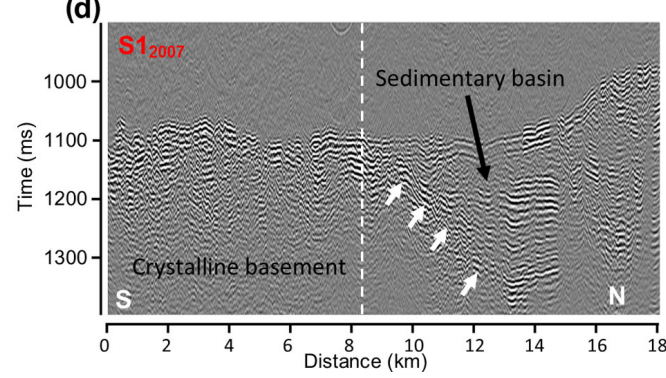

(e)

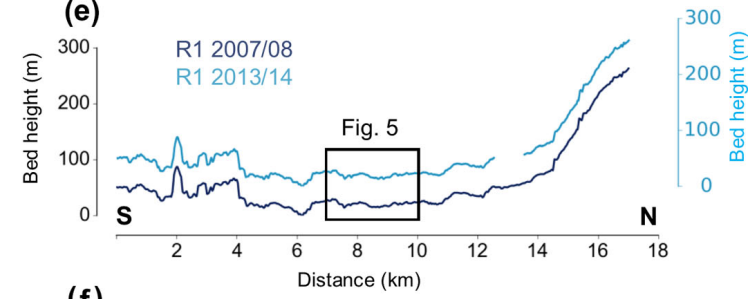

(f)

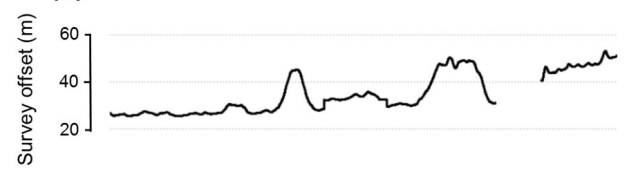

(g)
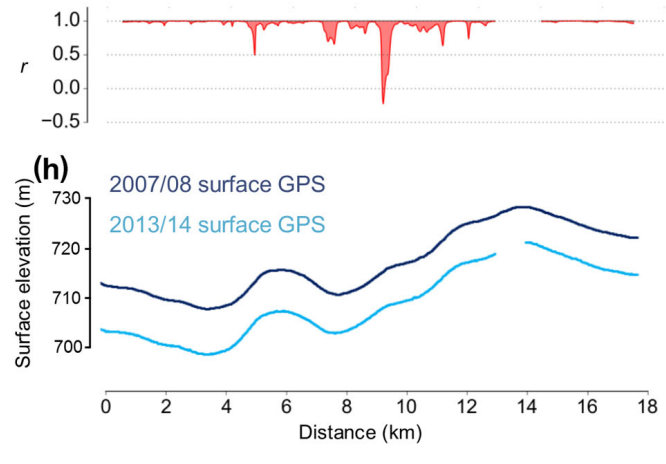

Figure 2. Geophysical data and bed picks from PIG. (a) Radar derived DEM from PIG showing the location of radar (black line) and seismic survey (red line). (b, c) processed radargrams of repeat radar surveys. (d) Processed seismic section of S1 (Smith et al., 2013). White arrows denote a dipping reflector demarcating a sedimentary basin. (e) Bed picks from repeat radar survey R1. (f) Plot showing the survey divergence between radar profiles in 2007/2008 and 2013/2014. (g) Correlation coefficient of repeat bed picks between 2008/2009 and 2013/2014 across a $500 \mathrm{~m}$ moving window. (h) Plot of surface elevation profiles derived from differential GPS measurements.

profile's bed picks across $500 \mathrm{~m}$ moving windows (Figs. 2 and 3). For $90 \%$ of the repeat radar tracks $r>0.9$, underscoring that there has been negligible morphological change for much of the surveys. For context, we performed the same correlation routine for the bed picks of repeat seismic survey data acquired in 1991, 1997 and 2004 along the $3.5 \mathrm{~km}$ profile C1 of RIS previously reported by Smith et al. (2007) (these results are shown in Fig. $4 \mathrm{e}$ ). At C1, the $\sim 0.5 \mathrm{~km} \mathrm{sec}-$ tion of track for which Smith et al. (2007) reported basal erosion between 1991 and 1997 yields $r \sim 0.5$, and the $\sim 100 \mathrm{~m}$ length of profile interpreted as hosting the growth of a drumlin between 1997 and 2004 returns $r \sim-0.2$.
There is only one location on PIG where $r$ is considerably lower than 0.9 ; this occurs between 8.5 and $9 \mathrm{~km}$ along profile R1 where $r$ spikes around a value of -0.2 (Fig. 2). Closer inspection of this location reveals a subtle change in the morphology of the bed picks between 2007/2008 and 2013/2014 (Fig. 5). At this site two bumps of $\sim 1-2 \mathrm{~m}$ height in $2007 / 2008$ are replaced in $2013 / 2014$ by a central ridge with two troughs $\sim 3 \mathrm{~m}$ in depth. However, it is possible that this change is caused by the aforementioned differences in horizontal resolution of the radar systems between surveys. We are therefore cautious to interpret this as a genuine change in bed morphology resulting from erosion and deposition. 

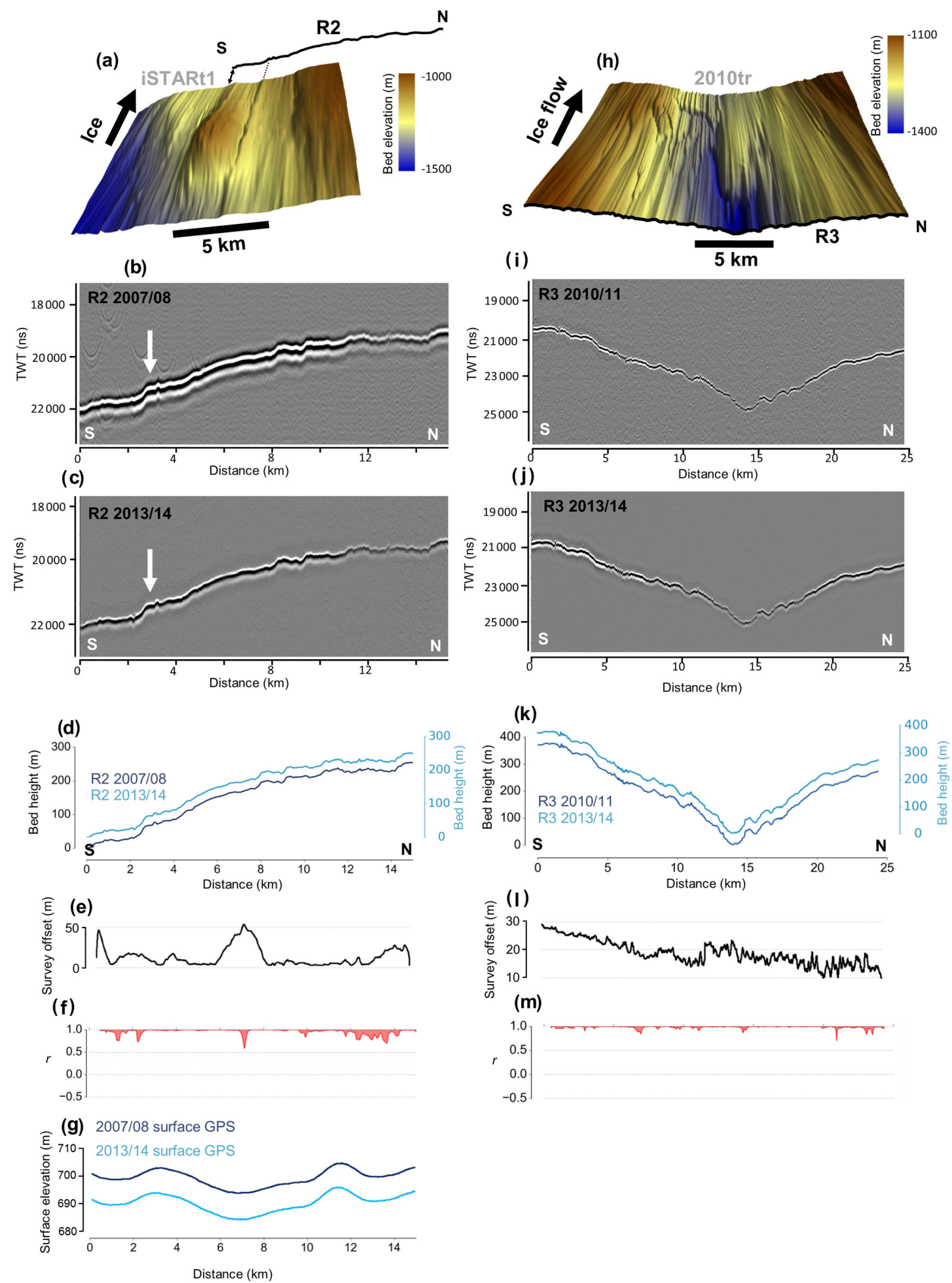

Figure 3. Geophysical data and bed picks from PIG. (a) Radar derived bed DEM (Bingham et al., 2017) showing the location of survey R2 $2 \mathrm{~km}$ downstream. (b, c) Processed radargrams of repeat radar surveys. (d) Bed picks from repeat radar survey R2. (e) Plot showing the survey divergence between radar profiles in 2007/2008 and 2013/2014. (f) Correlation coefficient of repeat bed picks between 2008/2009 and 2013/2014 across a $500 \mathrm{~m}$ moving window. (g) Plot of surface elevation profiles derived from differential GPS measurements. (h) Radar derived bed DEM (Bingham et al., 2017) showing the location of survey R3 at the upstream limit of the radar grid. (i, j) Processed radargrams of repeat radar surveys. (k) Bed picks from repeat radar survey R3. (l) Plot showing the survey divergence between radar profiles in $2007 / 2008$ and 2013/2014. (m) Correlation coefficient of repeat bed picks between 2010/2011 and 2013/2014 across a 500 m moving window. 


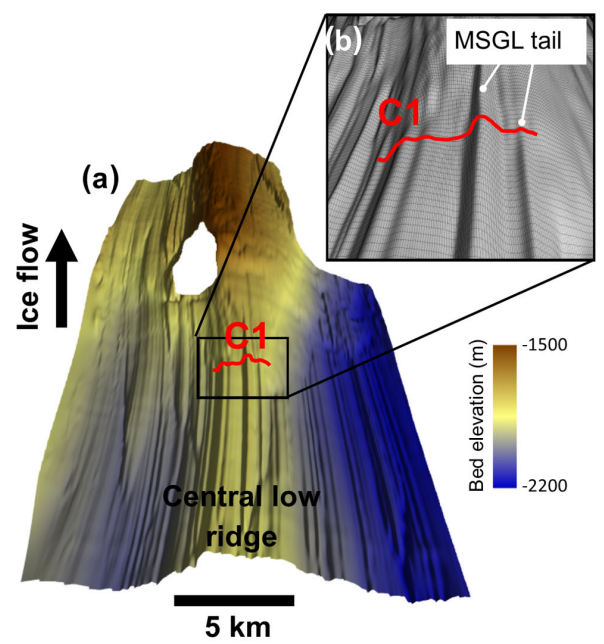

(c)
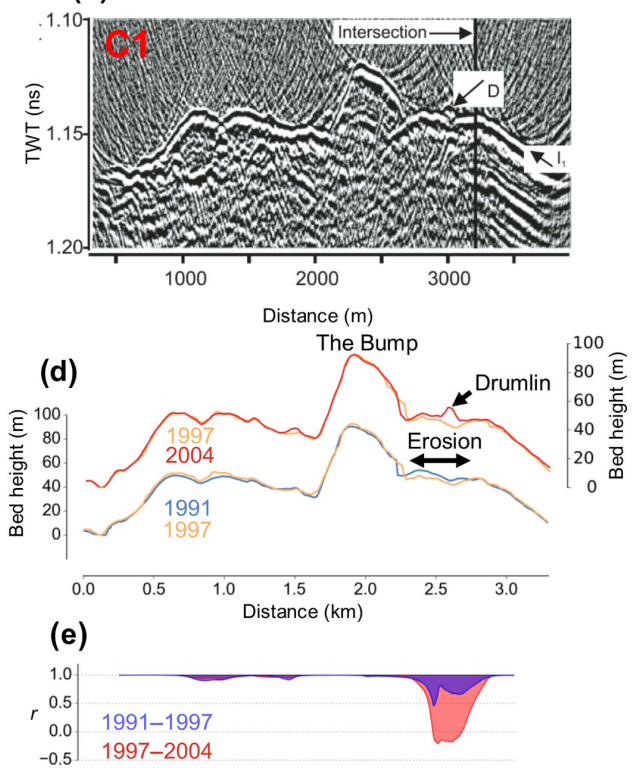

Figure 4. Geophysical data and bed picks from RIS (a) Radar derived bed DEM for RIS (King et al., 2016) showing geomorphology of the bed and the location of survey C1. (b) Close-up of the location of survey $\mathrm{C} 1$ showing the three-dimensional character of the bed. (c) Processed seismic section of survey C1. (d) Bed picks from repeat seismic surveys showing erosion and drumlin formation between 1991 and 2004 (Smith et al., 2007). (e) Correlation coefficient of repeat bed picks between 1991 and 2004 across a $500 \mathrm{~m}$ moving window.

\section{Discussion}

The prevailing picture that emerges from our $58 \mathrm{~km}$ of repeat surveys of PIG's bed is one of little measurable change having been effected to the ice stream's basal topography and morphology over the 3-7 year timescale. This is despite significant changes occurring to ice-flow speeds and ice-surface elevations over the same periods (Table 1), and the observations of active erosion and deposition made over similar timescales at RIS (Fig. 4); at RIS ice has experienced little to no dynamic thinning and ice flow is essentially stable (Table 1). In the following discussion we firstly consider how these apparently different behaviours between the ice beds of PIG and RIS can be reconciled (Sect. 4.1). We then turn to the implications of our results for the understanding of processes of sediment erosion, transport and deposition beneath ice streams and implications for future monitoring of the bed (Sect. 4.2).

\subsection{Are ice-stream beds dynamic?}

The only precedent for the measurements obtained here from PIG in terms of repeat geophysical survey over comparable timescales is that from RIS where erosion and deposition on the order of $\sim 1 \mathrm{~m} \mathrm{a}^{-1}$ were observed in association with morphological changes at the bed (Smith et al., 2007). Here we assess whether the lack of comparable changes observed at PIG can be explained by contrasting glaciological, hydrological and basal characteristics to the RIS survey site, and whether either is likely to be more representative of wider changes occurring at the beds of Antarctic ice streams.

The first notable difference between PIG and RIS is the broad subglacial topography. Each of the repeat surveys on PIG was conducted across the $30 \mathrm{~km}$-wide, $\sim 2000 \mathrm{~m}$ deep, main ice-stream trunk where, at the multi-km wavelength, the bed is largely flat along and across flow (Vaughan et al., 2006). By contrast, the repeat survey location on RIS, though also traversing the ice-stream trunk, overlies a notable topographic ridge ("Central low ridge") that abuts $\sim 350 \mathrm{~m}$ vertically upwards into the central $\sim 5 \mathrm{~km}$ width of the $\sim 30 \mathrm{~km}$ wide, $\sim 2000 \mathrm{~m}$ deep ice-stream trunk (Fig. $4 \mathrm{a}$ ). There is, therefore, a clear contrast in the gross topographic shape of the cross-sectional bed profile between the PIG and RIS repeat survey sites; and we note that the flat-bedded trough of PIG is more characteristic of the majority of ice streams in West Antarctica (Fretwell et al., 2013). Turning to the finer, sub-km morphological character of each site, detailed ground-based radar surveys of PIG's trunk (Figs. 2 and 3, and see further imagery in Bingham et al., 2017) have depicted ubiquitous mega-scale glacial lineations (MSGL) across all regions of PIG's trunk, indicative of the widespread presence of deforming sediment (Clark, 1993; Stokes and Clark, 2001; Spagnolo et al., 2016). MSGL with mean amplitudes $\sim 10 \mathrm{~m}$ and a mode spacing of $300-400 \mathrm{~m}$ are also pervasive surrounding the RIS repeat survey site (Fig. 4a) but, unlike PIG, within the MSGL themselves linear features with much higher amplitudes (up to $70 \mathrm{~m}$ ) are observed; King et al. (2016) termed these features "tapering drumlins". 


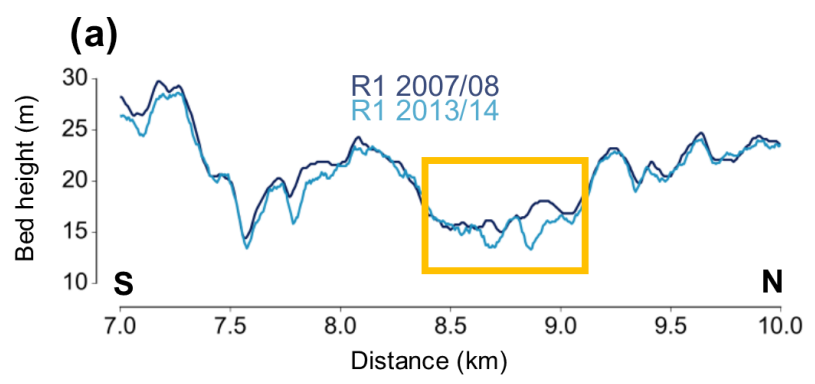

(b)

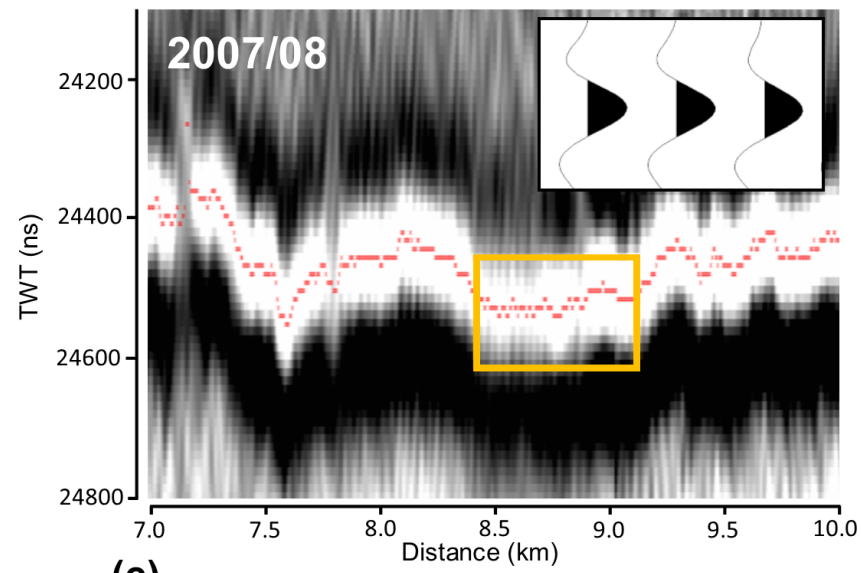

(c)

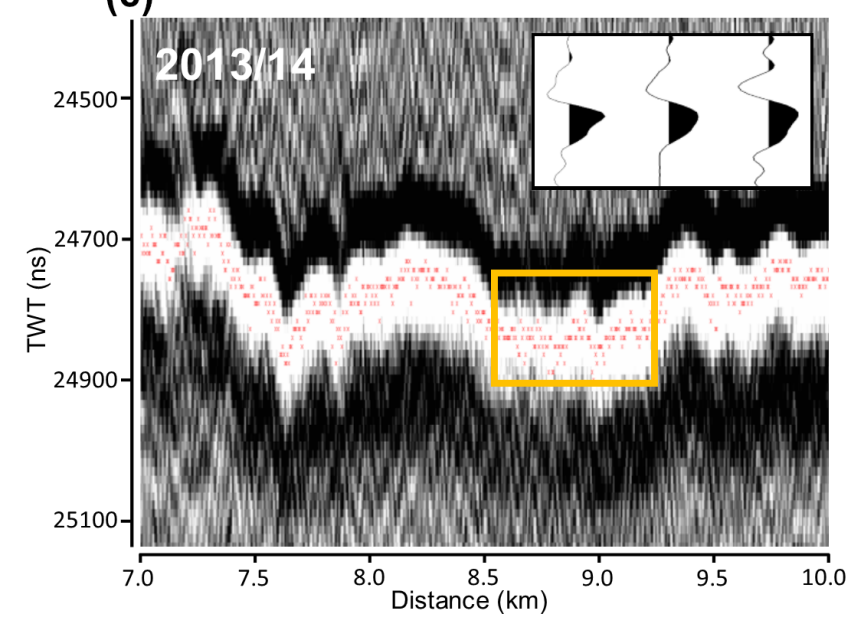

Figure 5. Close-up view of change in bed morphology between $2007 / 2008$ and 2013/2014 identified in survey R1. Yellow boxes outline the area of change identified as having a low correlation $(r=-0.2)$. (a) Smoothed bed picks from radar data. (b, c) Raw bed picks (red dots) of the basal reflector in 2007/2008 and 2013/2014. Inset plots show representative traces sampled from the bed reflector.

The physical properties of the bed between PIG and RIS also differ. Seismic reflection surveying of several sites along PIG's trunk, including upstream and downstream of our repeat survey sites, has confirmed that the bed immediately below the ice pervasively consists of dilated sediments, which are at least several metres thick (Smith et al., 2013; Brisbourne et al., 2017). Along seismic profile $\mathrm{S}_{2007}$ potential- field data indicate that a transition from sedimentary to crystalline bedrock lies beneath the cap of deformable sediments (at position $9 \mathrm{~km}$ on Fig. 2d) (Smith et al., 2013), but the repeat survey of $\mathrm{S} 1$ in $2014 / 2015\left(\mathrm{S1}_{2014}\right)$ exhibited no change to acoustic impedance anywhere along this profile (Brisbourne et al., 2017), reinforcing the notion of a relatively stable basal environment despite the transition in geology below the deforming till layer. By contrast, the bed around RIS profile site $\mathrm{C} 1$ is characterised by a "patchwork" of soft, deforming sediments contrasting with regions of basal sliding indicative of more consolidated sediments (Smith and Murray, 2009; Smith et al., 2015). Notably, the areas of deforming sediment coincide with topographic highs such as the feature known as "The Bump" (Smith, 1997) (Fig. 4c). Changes in acoustic impedance were detected for parts of the RIS repeat profile between 1997 and 2004, and were interpreted as changes in hydrological conditions within subglacial sediments affecting till porosity (Smith et al., 2007).

A third key difference between the PIG and RIS repeat survey sites is the degree to which the survey sites are affected by tidal influences, and the potential effects this can have on subglacial hydrology. High temporal resolution GPS monitoring of ice motion at RIS site $\mathrm{C} 1,10 \mathrm{~km}$ upstream of the grounding line, has shown that horizontal ice velocity varies by $\sim 20 \%$ on fortnightly timescales in response to tidally modulated vertical displacement of the FilchnerRonne Ice Shelf (Gudmundsson, 2006, 2007; Murray et al., 2007; Minchew et al., 2017). In addition, passive seismic monitoring has demonstrated increased seismic activity during tidal cycles (Aðalgeirsdóttir et al., 2008). Numerical modelling studies have suggested that the velocity oscillations are transmitted by tidally-forced fluctuations in basal water pressure, that alter the pore pressure of basal sediments and thus effective pressure at the bed (Thompson et al., 2014; Rosier et al., 2015). These observations suggest that the hydrological system beneath the RIS survey site is prone to significant dynamism and reorganisation over short timescales. However, Minchew et al. (2017) suggest that weak shear margins are a more dominant factor in the propagation of tidally induced horizontal ice-flow variability compared to fluctuations in basal water pressure.

High resolution GPS monitoring at several sites along PIG's main trunk showed no tidal signal in ice motion even $55 \mathrm{~km}$ upstream from the grounding line (Scott et al., 2009), which lies well downstream of our repeat radar sites R1R3. The ubiquitous dilated till layer that overlies a relatively flat bed at each of the PIG survey sites provides suitable conditions for a stable, distributed drainage system (Weertman, 1972; Alley, 1989; Engelhardt et al., 1990; Engelhardt and Kamb, 1997) potentially in the form of a canal network as suggested in the upstream catchment of neighbouring Thwaites Glacier (Schroeder et al., 2013), upstream RIS (King et al., 2004) and Whillans Ice Stream (Engelhardt and Kamb, 1997). In the absence of a dynamic hydrological system, sediment mobility facilitated by fluvial transport in sub- 
glacial sheets or channels (cf. Weertman, 1972; Walder and Fowler, 1994; Fowler, 2010; Kyrke-Smith and Fowler, 2014) may be restricted and likely be more stable over time, thereby limiting the rate of erosion and sediment transport detectable within the precision of repeat geophysical measurements.

We therefore consider the possibility that rapid erosion and bed reorganisation on the scale observed beneath RIS is an exception rather than the rule. Surface velocity inversions along PIG's main trunk suggest that most of its bed is subjected to low basal shear stress, except for some discrete "ribs" of high basal traction spanning the trunk downstream from our measurements (Sergienko and Hindmarsh, 2013). We suggest therefore that low sediment transport rates might be expected over much of PIG's bed as a consequence of the generally low basal shear stresses at all of our repeat measurement sites, and that future investigation of bed variation needs to be targeted towards an area of high inferred basal traction.

The apparent stability of the bed we observe is also worth considering in the context of debate concerning strain distribution in deforming beds and associated till rheology. The resolution of our data limits the scope of any firm conclusions but may contribute to further discussion on this issue. Field observations and models have argued for viscous (Boulton and Hindmarsh, 1987; Alley et al., 1987; Hindmarsh, 1998) and plastic (Kamb, 1991; Tulaczyk et al., 2000; Iverson, 2010) deformation of subglacial sediments. Subglacial till transport models invoking either viscous or plastic rheology demonstrate that deformation depth increases with effective pressure. Uneven terrains on an ice-stream bed would therefore translate into variable effective pressures and till fluxes, which might facilitate positive feedbacks over bumps and therefore the growth of bedforms (e.g. Hindmarsh, 1998; Fowler, 2000; Schoof, 2007). However, it remains unclear how rapidly bedforms can evolve, as although some studies have suggested rapid growth (Smith et al., 2007; Dowling et al., 2016) these might represent exceptions and a comprehensive analysis is missing. Such pressure-dependent growth will ultimately be controlled by the depth of deformation. It is also unclear whether bedform growth is always limited: they are typically characterised by a relatively welldefined size-frequency distribution, albeit positively skewed (e.g. Fowler et al., 2013; Hillier et al., 2016; Ely et al., 2018). In our study area, one would expect that the uneven terrain of the bed would translate into variable effective pressure and till fluxes and that topography would therefore evolve. The lack of morphological change that we have observed at the ice-stream bed could therefore be interpreted as evidence of very shallow deforming sediment, which might translate to a very low pace of bedform growth, not detectable within the relatively short interval of our repeat surveys. Alternatively, it might indicate that the ice-bed system has reached a point of "maturity" where bedform growth is inhibited by other physical factors. It is even possible that the entire PIG system is now experiencing net erosion due to its recent acceleration,

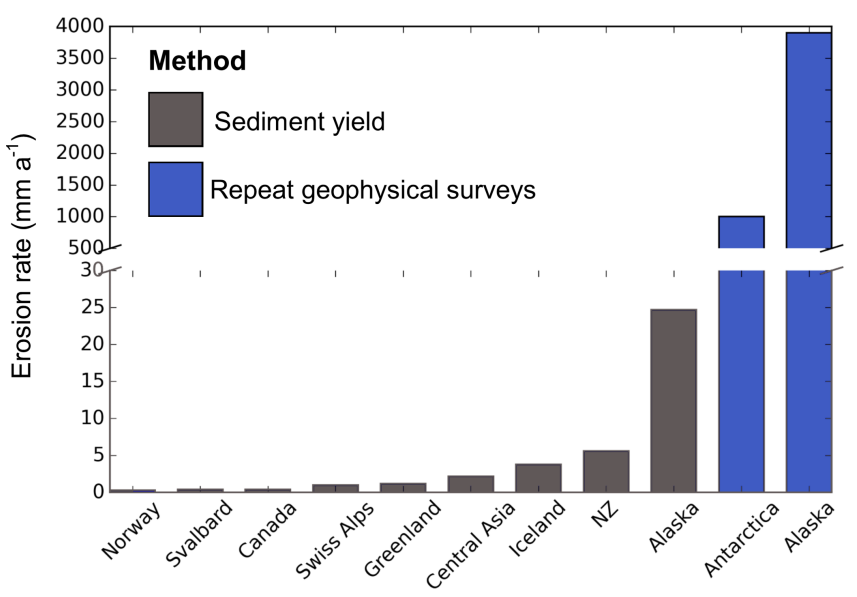

Figure 6. Mean erosion rates from previously published literature in a range of locations. Data taken from Hallet et al. (1996, and references therein), Koppes and Hallet (2006), Motyka et al. (2006), Cowton et al. (2012) and Smith et al. (2007, 2012).

yet the rate of such erosion must be very low for us not to be able to detect a lowering of the topography within the six year interval of our observations.

Geophysical surveys of other West Antarctic ice streams (Alley et al., 1986, Blankenship et al., 1986; Peters et al., 2006) have revealed shallow bed gradients and widespread deforming till similar to the surveyed sites on PIG. These characteristics are also evident in offshore records of palaeoice stream beds on the outer continental shelf of West Antarctica, where ice streams occupied shallow troughs in the sedimentary basement (Lowe and Anderson, 2002; Wellner et al., 2006; Larter et al., 2009; Graham et al., 2010). These offshore regions are characterised by ubiquitous MSGL (Spagnolo et al., 2014) that are also observed in the more extensive grid surveys surrounding our repeat surveys (Figs. 2a, 3a, h) (Bingham et al., 2017). The uniformity of these bedforms may reflect stable, self-organised bed conditions (cf. Spagnolo et al., 2017).

\subsection{Implications for subglacial sediment transport and future surveys}

The absence of detectable morphological change to the bed over the majority of the $\sim 60 \mathrm{~km}$ of bed profiles on PIG could be interpreted in three ways: (1) that no sediment erosion/transport/deposition is occurring at the measured sites; (2) that erosion/deposition is occurring but at rates too low to be detected within the vertical range resolution of the radar; or (3) that the subglacial till flux is in a steady state wherein sediment transport is active but is not altering the shape of the bed. The last of these would contradict modelling studies that suggest that pressure-dependent till fluxes dictate that there can be no steady-state till flux on an uneven basal interface (Hindmarsh, 1998; Fowler, 2000; Schoof, 2007). 
Prior to this study the few repeat geophysical surveys of the ice-bed interface in Alaska and Antarctica yielded subglacial erosion rates of 1000-3900 $\mathrm{mm} \mathrm{a}^{-1}$ (Motyka et al., 2006; Smith et al., 2007, 2012), far exceeding the 0.01$100 \mathrm{~mm} \mathrm{a}^{-1}$ range traditionally reported as characteristic of glacial settings using proglacial sediment yields (Hallet et al., 1996; Koppes and Hallet, 2006; Koppes and Montgomery, 2009; Cowton et al., 2012; Herman et al., 2015) (Fig. 6). Consequently, there has been growing consensus that subglacial erosion and transport is likely to be high, i.e. of the order of $\mathrm{m} \mathrm{a}^{-1}$, beneath thick, warm-based ice as manifested by polar ice streams. Observations of substantial till deposition at the grounding lines of contemporary and palaeo-ice streams in the West Antarctic support this view (Anandakrishnan et al., 2007; Batchelor and Dowdeswell, 2015). The precision of our measurements, essentially defined by the vertical range resolution of the radar, means that the maximum possible erosion rate that could go undetected along our profiles is $500 \mathrm{~mm} \mathrm{a}^{-1}$.

Aside from the repeat geophysical studies conducted in Antarctica by Smith et al. (2007, 2012), the only other location where this method has been used is southeast Alaska where Motyka et al. (2006) found exceptionally high erosion rates of up to $3.9 \pm 0.8 \mathrm{~m} \mathrm{a}^{-1}$ over a period of 14 years (Fig. 6). However, this setting is unique and these exceptional erosion rates occurred during short episodes of glacier advance over glaciomarine and outwash sediments driven by ice-sediment dynamics (Motyka et al., 2006; Brinkerhoff et al., 2017). Indeed, erosion rates in southern Alaska are the highest reported for any region. These high erosion rates are associated with high precipitation rates, active tectonic uplift and glaciofluvial evacuation of unlithified sediments (Hallet et al., 1996; Motyka et al., 2006). The equally rapid erosion observed by Smith et al. $(2007,2012)$ therefore evokes a glaciofluvial mechanism. Emerging evidence of subglacial hydrology from West Antarctica shows that meltwater can be stored and released over short timescales through interconnected subglacial lakes and channels (Wingham et al., 2006; Fricker et al., 2007; Fricker and Scambos, 2009; Smith et al., 2017). In our survey area there is no evidence from radar (Bingham et al., 2017) or seismic data (Brisbourne et al., 2017) that indicates the presence of subglacial lakes or concentrated meltwater channels. However, in Smith et al.'s (2012) repeat seismic measurement over $\sim 50$ years, rapid erosion of $1 \mathrm{~m} \mathrm{a}^{-1}$ was detected $\sim 25 \mathrm{~km}$ downstream of survey R3 (EHT31 in Fig. 1b). At this location the bed is also smooth and there is no indication from satellite or geophysical data of rapid meltwater drainage events or channelised meltwater flow (Smith et al., 2012). A possible explanation for the discrepancy between erosion observed at this location and the results of this study is a timescale bias (Ganti et al., 2016). Smith et al.'s (2012) study may have captured intermittent episodes of erosion not captured by our 3-6 year survey intervals.
In Sect. 3, we showed that while the majority of the repeat radar profiles evince negligible morphological change, there is one $\sim 0.5 \mathrm{~km}$ section of profile $\mathrm{R} 1$ where a possible reorganisation of the bed is expressed as a morphological change in the basal reflector (Fig. 5). This region of the bed broadly coincides with a transition from thin $(\leq 10 \mathrm{~m})$ sediment overlying a crystalline basement to a deep sedimentary basin imaged in seismic and potential field surveys (Smith et al., 2013). A change in basal drag and ice velocity is also associated with this boundary. It is likely that such boundaries influence subglacial hydrological pathways and, hence, basal ice motion. This exemplifies the importance of the sampling location and periods of measurement to any study attempting to capture subglacial sedimentary processes. For example, the location where Smith et al. (2007) monitored deposition (drumlin formation) on RIS between 1997 and 2004 is positioned at the end of a drumlin tail subsequently imaged in a wider radar survey of the region (King et al., 2009, 2016) (Fig. 4b). These repeat measurements may have been fortuitously timed to capture the extension of the drumlin tail. The anisotropic morphology of tapering drumlins and MSGL present beneath RIS (King et al., 2016) may not lend itself well to the detection of change from 2-D surveys driven orthogonal to ice flow. Dynamic change in these bedforms may be expressed as downstream migration of a propagating sediment front that would be difficult to detect without more extensive and/or higher-density coverage of repeat surveys over longer timescales.

\section{Conclusions}

We have analysed $\sim 60 \mathrm{~km}$ of repeat radar surveys acquired from Pine Island Glacier, West Antarctica, between austral seasons 2007/2008 and 2013/2014. The results showed that little morphological change occurred at the bed over this period. The absence of large signals of erosion or deposition contrasts with erosion/deposition measured on nearby Rutford Ice Stream between 1991 and 2004 (Smith et al., 2007), and with inferred erosion of $\sim 1 \mathrm{~m} \mathrm{a}^{-1}$ at Pine Island Glacier over a half century (1960-2009; Smith et al., 2012). We attribute the negligible detection of morphological change at the bed of Pine Island Glacier on the sub-decadal timescale to the ubiquitous presence of a deforming till layer, wherein sediment transport is in steady state such that sediment is transported along the basal interface without inducing measurable vertical displacement to the radar-sounded basal interface. Moreover, none of the survey sites on Pine Island Glacier have experienced short-term variations in ice velocity (Scott et al., 2009) diagnostic of active hydrological systems capable of mobilising sediment (Thompson et al., 2014; Rosier et al., 2015). By comparison, the high subglacial erosion and deposition rates reported from Rutford Ice Stream occurred where the ice is overriding a topographic rise $350 \mathrm{~m}$ high, there are sharp contrasts in subglacial sediment proper- 
ties, and the subglacial system likely experiences short-term variability influenced by tidal oscillations (Aðalgeirsdóttir et al., 2008; Thompson et al., 2014; Rosier et al., 2015).

The surveys presented in this study have increased the length, by an order or magnitude, of the available records of repeat measurements of Antarctic ice-stream beds. However, these environments remain poorly sampled. The surveys of Pine Island Glacier and Rutford Ice Stream have shown that improved understanding of the dynamism of the ice-sheet bed may best be gained from a multi-method survey approach, involving (1) high-density radar grid surveying to image the subglacial landscape and provide spatial context, (2) seismic survey to discern the physical properties of the basal interface and (3) repeated seismic and/or radar profiles at the same site undertaken over sub-decadal to decadal timescales. Our findings also show the importance of the physical properties of the bed at each site to the sediment erosion and deposition that could be detected, underscoring the requirement to sample sites that, as a whole, capture a representative range of basal conditions. Models of basal drag inverted from satellite-imaged surface properties (e.g. Joughin et al., 2009; Arthern et al., 2015) offer the best opportunities to guide site selection.

Data availability. All the data in this paper are available from the lead author by request and will be made available on the NERC/iSTAR GIS site, http://gis.istar.ac.uk/.

Author contributions. Radar and seismic data from 2007/2008 were acquired by RGB; radar data from 2010/2011 by ECK; radar data from 2013/2014 by DD, RGB, AMS and DGV; and seismic data from $2014 / 2015$ by AMB, AMS and DD. Radar data were processed by DD, RGB and ECK and seismic data by AMB and AMS. Sentinel-1 velocity estimates for each geophysical site were produced by AEH. DD analysed the data and wrote the paper. All authors contributed edits to the final manuscript.

Competing interests. The authors declare that they have no conflict of interest.

Acknowledgements. Damon Davies was supported by the NERC Training Grant NE/K011189/1 awarded to Robert Bingham. All fieldwork was supported by funding from the UK Natural Environment Research Council (NERC) iSTAR Programme Grants NE/J005665 (RGB/ECK/AMS/AMB/DGV) and NE/J005681 (AEH), NERC grants NE/B502287 (ECK/AMS) and NE/J004766 (MS), and the British Antarctic Survey (BAS) Polar Science for Planet Earth Programme. Anna E. Hogg was supported by an independent research fellowship (no. 4000112797/15/I-SBo) jointly funded by the European Space Agency, the University of Leeds and the British Antarctic Survey. We would like to thank all members of the iSTAR traverses of Pine Island Glacier for assistance with field data acquisition in 2013/2014 and 2014/2015;
Mark Baird, Tim Gee, James Wake and Jonny Yates for field operational support during iSTAR; Feargal Buckley, Chris Griffiths and Julian Scott for field assistance in 2007/2008 and David Routledge for field assistance in 2010/2011. We are especially grateful for the dedicated and professional support of BAS Operations and Logistics without whom this study would not have been possible. Finally we are grateful to Anders Damsgaard and Huw Horgan for their insightful comments in reviewing this work which has led to a much improved manuscript.

Edited by: Chris R. Stokes

Reviewed by: Huw Horgan and Anders Damsgaard

\section{References}

Aðalgeirsdóttir, G., Smith, A. M., Murray, T., King, M. A., Makinson, K., Nicholls, K. W., and Behar, A. E.: Tidal influence on Rutford Ice Stream, West Antarctica: observations of surface flow and basal processes from closely spaced GPS and passive seismic stations, J. Glaciol., 54, 715-724, 2008.

Alley, R.: Water-pressure coupling of sliding and bed deformation: I. Water system, J. Glaciol., 35, 108-118, 1989.

Alley, R., Cuffey, K., Evenson, E., Strasser, J., Lawson, D., and Larson, G.: How glaciers entrain and transport basal sediment: physical constraints, Quaternary Sci. Rev., 16, 1017-1038, 1997.

Alley, R. B.: Continuity comes first: recent progress in understanding subglacial deformation, Geol. Soc. SP, 176, 171-179, 2000.

Alley, R. B., Blankenship, D. D., Bentley, C. R. and Rooney, S. T.: Deformation of till beneath ice stream B, West Antarctica, Nature, 322, 57-59, 1986.

Alley, R. B., Blankenship, D. D., Rooney, S. T., and Bentley, C. R.: Till beneath ice stream B: 4. A coupled ice-till flow model, J. Geophys. Res.-Sol.-Ea., 92, 8931-8940, 1987.

Alley, R. B., Blankenship, D. D., Rooney, S. T., and Bentley, C. R.: Sedimentation beneath ice shelves - the view from ice stream, B. Mar. Geol., 85, 101-120, 1989.

Alley, R. B., Lawson, D. E., Larson, G. J., Evenson, E. B., and Baker, G. S.: Stabilizing feedbacks in glacier-bed erosion, Nature, 424, 758-760, 2003.

Alley, R. B., Anandakrishnan, S., Dupont, T. K., Parizek, B. R., and Pollard, D.: Effect of sedimentation on ice-sheet grounding-line stability, Science, 315, 1838-1841, 2007.

Anandakrishnan, S. and Alley, R.: Stagnation of Ice Stream C, West Antarctica by water piracy, Geophys. Res. Lett., 24, 265-268, https://doi.org/10.1029/96GL04016, 1997.

Anandakrishnan, S., Catania, G. A., Alley, R. B., and Horgan, H. J.: Discovery of till deposition at the grounding line of Whillans Ice Stream, Science, 315, 1835-1838, https://doi.org/10.1126/science.1138393, 2007.

Arthern, R. J., Hindmarsh, R. C. A., and Williams, C. R.: Flow speed within the Antarctic ice sheet and its controls inferred from satellite observations, J. Geophys. Res., 120, 1171-1188, 2015.

Batchelor, C. L. and Dowdeswell, J. A.: Ice-sheet grounding-zone wedges (GZWs) on high-latitude continental margins, Mar. Geol., 363, 65-92, https://doi.org/10.1016/j.margeo.2015.02.001, 2015. 
Bentley, C., Lord, N., and Liu, C.: Radar reflections reveal a wet bed beneath stagnant Ice Stream. C and a frozen bed beneath ridge BC, West Antarctica, J. Glaciol., 44, 149-156, 1998.

Bingham, R. G., Vaughan, D. G., King, E. C., Davies, D., Cornford, S. L., Smith, A. M., Arthern, R. J., Brisbourne, A. M., De Rydt, J., Graham, A. G. C., Spagnolo, M., Marsh, O. J., and Shean, D. E.: Diverse landscapes beneath Pine Island Glacier influence ice flow, Nat. Commun., 8, 1618, https://doi.org/10.1038/s41467017-01597-y, 2017.

Blankenship, D. D., Bentley, C. R., Rooney, S. T., and Alley, R. B.: Seismic measurements reveal a saturated porous layer beneath an active Antarctic ice stream, Nature, 322, 54-57, 1986.

Boulton, G. S. and Hindmarsh, R. C. A., Sediment deformation beneath glaciers: rheology and geological consequences, J. Geophys. Res., 92, 9059-9082, 1987.

Brinkerhoff, D., Truffer, M., and Aschwanden, A.: Sediment transport drives tidewater glacier periodicity, Nat. Commun., 8, p. 90, https://doi.org/10.1038/s41467-017-00095-5, 2017.

Brisbourne, A. M., Smith, A. M., Vaughan, D. G., King, E. C., Davies, D., Bingham, R. G., Smith, E. C., Nias, I. J., and Rosier, S. H. R.: Bed conditions of Pine Island Glacier, West Antarctica, J. Geophys. Res.-Earth, 122, 419-433, https://doi.org/10.1002/2016JF004033, 2017.

Clark, C. D.: Mega-scale glacial lineations and cross-cutting ice-flow landforms, Earth Surf. Proc. Land., 18, 1-29, https://doi.org/10.1002/esp.3290180102, 1993.

Conway, H., Catania, G., Raymond, C. F., Gades, A. M., Scambos, T. A., and Engelhardt, H.: Switch of flow direction in an Antarctic ice stream, Nature, 419, 465-467, 2002.

Cowton, T., Nienow, P., Bartholomew, I., Sole, A., and Mair, D.: Rapid erosion beneath the Greenland ice sheet, Geology, 40, 343-346, 2012.

Cuffey, K. and Alley, R. B.: Is erosion by deforming subglacial sediments significant? (Toward till continuity), Ann. Glaciol., 22, 17-24, 1996.

Damsgaard, A., Egholm, D. L., Piotrowski, J. A., Tulaczyk, S., Larsen, N. K., and Tylmann, K.: Discrete element modelling of subglacial sediment deformation, J. Geophys. Res.-Earth, 118, 2230-2242, 2013.

Damsgaard, A., Egholm, D. L., Beem, L. H., Tulaczyk, S., Larsen, N. K., Piotrowski, J. A., and Siegfried, M. R.: Ice flow dynamics forced by water pressure variations in subglacial granular beds, Geophys. Res. Lett., 43, 12165-12173, 2016.

DeConto, R. M. and Pollard, D.: Contribution of Antarctica to past and future sea-level rise, Nature, 531, 591-597, 2016.

Dowling, T. P. F., Moller, P., and Spagnolo, M.: Rapid subglacial streamlined bedform formation at a calving bay margin, J. Quaternary Sci., 31, 879-892, https://doi.org/10.1002/jqs.2912, 2016.

Ely, J. C., Clark, C. D., Ng, F., Spagnolo, M., Hughes, A. L. C., and Stokes, C. R.: Using the size and position of drumlins to understand how they grow, interact and evolve, Earth Surf. Proc. Land., 43, 1073-1087, https://doi.org/10.1002/esp.4241, 2018.

Engelhardt, H. and Kamb, B.: Basal hydraulic system of a West Antarctic ice stream: constraints from borehole observations, J. Glaciol., 43, 207-229, 1997.

Engelhardt, H. and Kamb, B.: Basal sliding of Ice Stream B, West Antarctica, J. Glaciol., 44, 223-230, 1998.
Engelhardt, H., Humphrey, N., Kamb, B., and Fahnestock, M., Physical conditions at the base of a fast moving Antarctic ice stream, Science, 248, 57-59, 1990.

Fowler, A. C.: The formation of subglacial streams and mega-scale glacial lineations, P. R. Soc. Lond. A Mat., 466, 3181-3201, 2010.

Fowler, A. C., Spagnolo, M., Clark, C. D., Stokes, C. R., Hughes, A. L. C., and Dunlop, P.: On the size and shape of drumlins, International Journal on Geomathematics, 4, 155-165, 2013.

Fretwell, P., Pritchard, H. D., Vaughan, D. G., Bamber, J. L., Barrand, N. E., Bell, R., Bianchi, C., Bingham, R. G., Blankenship, D. D., Casassa, G., Catania, G., Callens, D., Conway, H., Cook, A. J., Corr, H. F. J., Damaske, D., Damm, V., Ferraccioli, F., Forsberg, R., Fujita, S., Gim, Y., Gogineni, P., Griggs, J. A., Hindmarsh, R. C. A., Holmlund, P., Holt, J. W., Jacobel, R. W., Jenkins, A., Jokat, W., Jordan, T., King, E. C., Kohler, J., Krabill, W., Riger-Kusk, M., Langley, K. A., Leitchenkov, G., Leuschen, C., Luyendyk, B. P., Matsuoka, K., Mouginot, J., Nitsche, F. O., Nogi, Y., Nost, O. A., Popov, S. V., Rignot, E., Rippin, D. M., Rivera, A., Roberts, J., Ross, N., Siegert, M. J., Smith, A. M., Steinhage, D., Studinger, M., Sun, B., Tinto, B. K., Welch, B. C., Wilson, D., Young, D. A., Xiangbin, C., and Zirizzotti, A.: Bedmap2: improved ice bed, surface and thickness datasets for Antarctica, The Cryosphere, 7, 375-393, https://doi.org/10.5194/tc-7-375-2013, 2013.

Fricker, H. A. and Scambos, T., Connected subglacial lake activity on lower Mercer and Whillans ice streams, West Antarctica, 2003-2008, J. Glaciol., 55, 303-315, 2009.

Fricker, H. A., Scambos, T., Bindschadler, R., and Padman, L.: An active subglacial water system in West Antarctica mapped from space, Science, 315, 1544-1548, https://doi.org/10.1126/science.1136897, 2007.

Ganti, V., Hagke, C. V., Scherler, D., Lamb, M. P., Fischer, W. W., and Avouac J.-P.: Time scale bias in erosion rates of glaciated landscapes, Science Advances, 2, e1600204, https://doi.org/10.1126/sciadv.1600204, 2016.

Graham, A. G. C., Larter, R. D., Gohl, K., Dowdeswell, J. A., Hillenbrand, C.-D., Smith, J. A., Evans, J., Kuhn, G., and Deen, T.: Flow and retreat of the Late Quaternary Pine IslandThwaites palaeo-ice stream, West Antarctica, J. Geophys. Res., 115, F03025, https://doi.org/10/1029/2009JF001482, 2010.

Gudmundsson, G. H.: Fortnightly variations in the flow velocity of Rutford Ice Stream, West Antarctica, Nature, 444, 1063-1064, 2006.

Gudmundsson, G. H.: Tides and the flow of Rutford Ice Stream, West Antarctica, J. Geophys. Res.-Earth, 112, 1063-1064, https://doi.org/10.1029/2006JF000731, 2007.

Hallet, B., Hunter, L., and Bogen, J.: Rates of erosion and sediment evacuation by glaciers: A review of field data and their implications, Global Planet. Change, 12, 213-235, 1996.

Herman, F., Beaud, F. Champagnac, J.-D. Lemieux, J.-M., and Sternai, P.: Glacial hydrology and erosion patterns: a mechanism for carving glacial valleys, Earth Planet. Sc. Lett., 310, 498-508, 2011.

Herman, F., Beyssac, O., Brughelli, M., Lane, S. N., Leprince, S., Adatte, T., Lin, J. Y. Y., Avouac, J.-P., and Cox, S. C.: Erosion by an alpine glacier, Science, 350, 193-195, https://doi.org/10.1126/science.aab2386, 2015. 
Hillier, J. K., Kougioumtzoglou, I. A., Stokes, C. R., Smith, M. J., Clark, C. D., and Spagnolo, M.: Exploring explanations of subglacial bedform sizes using statistical models, PloS ONE, 11, e0159489, https://doi.org/10.1371/journal.pone.0159489, 2016.

Hindmarsh, R. C.: The stability of a viscous till sheet coupled with ice flow, considered at wavelengths less than the ice thickness, J. Glaciol., 44, 285-292, 1998.

Hogg, A., Shepherd, A., Cornford, S. L., Briggs, K. H., Gourmelen, N., Graham, J. A., Joughin, I., Mouginot, J., Nagler, T., Payne, A. J., Rignot, E., and Wuite, J.: Increased ice flow in Western Palmer Land linked to ocean melting, Geophys. Res. Lett., 9, 4159-4167, 2017.

Iverson, N. R.: Shear resistance and continuity of subglacial till: hydrology rules, J. Glaciol., 56, 1104-1114, 2010.

Iverson, N. R. and Iverson, R. M.: Distributed shear of subglacial till due to Coulomb slip, J. Glaciol., 47, 481-488, 2001.

Jamieson, S. S. R., Sugden, D. E., and Hulton, N. R. J.: The evolution of the subglacial landscape of Antarctica, Earth Planet. Sc. Lett., 293, 1-27, 2010.

Jenson, J. W., Clark, P. U., MacAyeal, D. R., Ho, C., and Vela, J. C.: Numerical modelling of advective transport of saturated deforming sediment beneath the Lake Michigan Lobe, Laurentide Ice Sheet, Geomorphology, 14, 157-166, 1995.

Joughin, I., Tulaczyk, S., Bamber, J. L., Blankenship, D., Holt, J. W., Scambos, T., and Vaughan, D. G.: Basal conditions for Pine Island and Thwaites Glaciers, West Antarctica, determined using satellite and airborne data, J. Glaciol., 55, 245-257, 2009.

Joughin, I., Smith, B. E., and Medley, B.: Marine ice sheet collapse potentially under way for the Thwaites Glacier basin, West Antarctica, Science, 344, 735-738, 2014.

Kamb, B.: Rheological nonlinearity and flow instability in the deforming bed mechanism of ice stream motion, J. Geophys. Res.Sol. Ea., 96, 16585-16595, 1991.

King, E. C., Woodward, J., and Smith, A. M.: Seismic evidence for a water-filled canal in deforming till beneath Rutford Ice Stream, West Antarctica, Geophys. Res. Lett., 31, https://doi.org/10.1029/2004GL020379, 2004.

King, E. C., Hindmarsh, R. C. A., and Stokes, C. R.: Formation of mega-scale glacial lineations observed beneath a West Antarctic ice stream, Nat. Geosci., 2, 585-588, https://doi.org/10.1038/NGEO581, 2009.

King, E. C., Pritchard, H. D., and Smith, A. M.: Subglacial landforms beneath Rutford Ice Stream, Antarctica: detailed bed topography from ice-penetrating radar, Earth Syst. Sci. Data, 8, 151-158, https://doi.org/10.5194/essd-8-151-2016, 2016.

Konrad, H., Gilbert, L., Cornford, S. L., Payne, A., Hogg, A., Muir, A., and Shepherd, A.: Uneven onset and pace of ice-dynamical imbalance in the Amundsen Sea Embayment, West Antarctica, Geophys. Res. Lett., 44, 910-918, 2017.

Koppes, M. and Hallet, B.: Erosion rates during rapid deglaciation in Icy Bay, Alaska, J. Geophys. Res., 111, https://doi.org/10.1029/2005JF000349, 2006.

Koppes, M. N. and Montgomery, D. R.: The relative efficacy of fluvial and glacial erosion over modern to orogenic timescales, Nat. Geosci., 2, 644-647, 2009.

Kyrke-Smith, T. M. and Fowler, A. C.: November, Subglacial swamps, P. Roy. Soc. Lond. A Mat., 470, 20140340, https://doi.org/10.1098/rspa.2014.0340, 2014.
Larter, R. D., Graham, A. G. C., Gohl, K., Kuhn, G., Hillenbrand, C. D., Smith, J. A., Deen, T. J., Livermore, R. A., and Schenke, H. W.: Subglacial bedforms reveal complex basal regime in a zone of paleo-ice stream convergence, Amundsen Sea embayment, West Antarctica, Geology, 37, 411-414, 2009.

Lowe, A. L. and Anderson, J. B.: Reconstruction of the West Antarctic Ice Sheet in Pine Island Bay during the Last Glacial Maximum and its subsequent retreat history, Quaternary Sci. Rev., 21, 1879-1897, 2002.

McMillan, M., Shepherd, A., Sundal, A., Briggs, K., Muir, A., Ridout, A., Hogg, A., and Wingham, D.: Increased ice losses from Antarctica detected by CryoSat-2, Geophys. Res. Lett., 41, 3899-3905, 2014.

Minchew, B., Simons, M., Riel, B., and Milillo, P.: Tidally induced variations in vertical and horizontal motion on Rutford Ice Stream, West Antarctica, inferred from remotely sensed observations, J. Geophys. Res.-Earth, 122, 167-190, 2017.

Motyka, R. J., Truffer, M., Kuriger, E. M., and Bucki, A. K.: Rapid erosion of soft sediments by tidewater glacier advance: Taku Glacier, Alaska, USA, Geophys. Res. Lett., 33, L24504, https://doi.org/10.1029/2006GL028467, 2006.

Mouginot, J., Rignot, E., and Scheuchl, B.: Sustained increase in ice discharge from the Amundsen Sea Embayment, West Antarctica, from 1973 to 2013, Geophys. Res. Lett., 41, 1576-1584, 2014.

Murray, T., Smith, A. M., King, M. A., and Weedon, G. P.: Ice flow modulated by tides at up to annual periods at Rutford Ice Stream, West Antarctica, Geophys. Res. Lett., 34, L18503, https://doi.org/10.1029/2007GL031207, 2007.

Nygård, A., Sejrup, H. P., Haflidason, H., Lekens, W. A. H., Clark, C. D. and Bigg, G. R.: Extreme sediment and ice discharge from marine-based ice streams: New evidence from the North Sea, Geology, 35, 395-398, 2007.

Park, J. W., Gourmelen, N., Shepherd, A., Kim, S. W., Vaughan, D. G., and Wingham, D. J.: Sustained retreat of the Pine Island Glacier, Geophys. Res. Lett., 40, 2137-2142, 2013.

Peters, L. E., Anandakrishnan, S., Alley, R. B., Winberry, J. P., Voigt, D. E., Smith, A. M., and Morse, D. L.: Subglacial sediments as a control on the onset and location of two Siple Coast ice streams, West Antarctica, J. Geophys. Res.-Sol. Ea., 111, B01302, https://doi.org/10.1029/2005JB003766, 2006.

Pritchard, H. D., Arthern, R. J., Vaughan, D. G., and Edwards, L. A.: Extensive dynamic thinning on the margins of the Greenland and Antarctic ice sheets, Nature, 461, 971-975, 2009.

Raiswell, R., Tranter, M., Benning, L. G., Siegert, M., De'Ath, R., Huybrechts, P., and Payne, T.: Contributions from glacially derived sediment to the global iron (oxyhydr)oxide cycle: implications for iron delivery to the oceans, Geochim. Cosmochim. Ac., 70, 2765-2780, 2006.

Rignot, E., Mouginot, J., and Scheuchl, B.: Ice flow of the Antarctic Ice Sheet, Science, 333, 1427-1430, 2011.

Rignot, E., Mouginot, J., Morlighem, M., Seroussi, H., and Scheuchl, B.: Widespread, rapid grounding line retreat of Pine Island, Thwaites, Smith, and Kohler glaciers, West Antarctica, from 1992 to 2011, Geophys. Res. Lett., 41, 3502-3509, 2014.

Rosier, S. H. R., Gudmundsson, G. H., and Green, J. A. M.: Temporal variations in the flow of a large Antarctic ice stream controlled by tidally induced changes in the subglacial water system, The Cryosphere, 9, 1649-1661, https://doi.org/10.5194/tc9-1649-2015, 2015. 
Schoof C.: Cavitation on deformable glacier beds, SIAM J. Appl. Math., 67, 1633-1653, 2007.

Schroeder, D. M., Blankenship, D. D., and Young, D. A.: Evidence for a water system transition beneath Thwaites Glacier, West Antarctica, P. Natl. Acad. Sci. USA, 110, 12225-12228, 2013.

Scott, J. B. T., Gudmundsson, G. H., Smith, A. M., Bingham, R. G., Pritchard, H. D., and Vaughan, D. G.: Increased rate of acceleration on Pine Island Glacier strongly coupled to changes in gravitational driving stress, The Cryosphere, 3, 125-131, https://doi.org/10.5194/tc-3-125-2009, 2009.

Sergienko, O. V. and Hindmarsh, R. C. A.: Regular patterns in frictional resistance of ice-stream beds seen by surface data inversion, Science, 342, 1086-1089, 2013.

Shepherd, A., Wingham, D. J., Mansley, J. A. D., and Corr, H. F. J.: Inland thinning of Pine Island Glacier, West Antarctica, Science, 291, 862-864, 2001.

Shepherd, A., Ivins, E. R., Geruo, A., Barletta, V. R., Bentley, M. J., Bettadpur, S., Briggs, K. H., Bromwich, D. H., Forsberg, R., Galin, N., Horwath, M., Jacobs, S., Joughin, I., King, M. A., Lenaerts, J. T. M., Li, J., Ligtenberg, S. R. M., Luckman, A., Luthcke, S. B., McMillan, M., Meister, R., Milne, G., Mouginot, J., Muir, A., Nicolas, J. P., Paden, J., Payne, A. J., Pritchard, H., Rignot, E., Rott, H., Sørensen, L. S., Scambos, T. A., Scheuchl, B., Schrama, E. J. O., Smith, B., Sundal, A. V., van Angelen, J. H., van de Berg,W. J., van den Broeke, M. R., Vaughan, D. G., Velicogna, I.,Wahr, J., Whitehouse, P. L.,Wingham, D. J., Yi, D., Young, D., and Zwally, H. J.: A reconciled estimate of ice-sheet mass balance, Science, 338, 1183-1189, 2012.

Smith, A. M.: Basal conditions on Rutford Ice Stream, West Antarctica, from seismic observations, J. Geophys. Res.-Sol. Ea., 102, 543-552, 1997.

Smith, A. M. and Murray, T.: Bedform topography and basal conditions beneath a fast-flowing West Antarctic ice stream, Quaternary Sci. Rev., 28, 584-596, 2009.

Smith, A. M., Murray, T., Nicholls, K. W., Makinson, K., Aðalgeirsdóttir, G., Behar, A. E., and Vaughan, D. G.: Rapid erosion, drumlin formation, and changing hydrology beneath an Antarctic ice stream, Geology, 35, 127-130, 2007.

Smith, A. M., Bentley, C. R., Bingham, R. G., and Jordan, T. A.: Rapid subglacial erosion beneath Pine Island Glacier, West Antarctica, Geophys. Res. Lett., 39, L12501, https://doi.org/10.1029/2012GL051651, 2012.

Smith, A. M., Jordan, T. A., Ferraccioli, F., and Bingham, R. G.: Influence of subglacial conditions on ice stream dynamics: Seismic and potential field data from Pine Island Glacier, West Antarctica, J. Geophys. Res.-Sol. Ea., 118, 1471-1482, 2013.

Smith, B. E., Gourmelen, N., Huth, A., and Joughin, I.: Connected subglacial lake drainage beneath Thwaites Glacier, West Antarctica, The Cryosphere, 11, 451-467, https://doi.org/10.5194/tc11-451-2017, 2017.

Smith, E. C., Smith, A. M., White, R. S., Brisbourne, A. M., and Pritchard, H. D.: Mapping the ice-bed interface characteristics of Rutford Ice Stream, West Antarctica, using microseismicity, J. Geophys. Res.-Earth, 120, 1881-1894, 2015.
Spagnolo, M., Clark, C. D., Ely, J. C., Stokes, C. R., Anderson, J. B., Andreassen, K., Graham, A. G. C., and King, E. C.: Size, shape and spatial arrangement of mega-scale glacial lineations from a large and diverse dataset, Earth Surf. Proc. Land., 39, 1432-1448, https://doi.org/10.1002/esp.3532, 2014.

Spagnolo, M., Phillips, E., Piotrowski, J., Rea, B. R., Clark, C. D., Stokes, C. R., Carr, S., Ely, J. C., Ribolini, A., Wysota, W., and Szuman, I.: Ice stream motion facilitated by a shallow-deforming and accreting bed, Nat. Commun., 7, 10723, https://doi.org/10.1038/ncomms10723, 2016.

Spagnolo, M., Bartholomaus, T. C., Clark, C. D., Stokes, C. R., Atkinson, N., Dowdeswell, J. A., Ely, J. C., Graham, A. G. C., Hogan, K. A., King, E. C., Larter, R. D., Livingstone, S. J., and Pritchard, H. D.: The periodic topography of ice stream beds: Insights from the Fourier spectra of mega-scale glacial lineations, J. Geophys. Res., 122, 1355-1373, 2017.

Stokes, C. and Clark, C.: Palaeo-ice streams, Quaternary Sci. Rev., 20, 1437-1457, 2001.

Thompson, J., Simons, M., and Tsai, V. C.: Modeling the elastic transmission of tidal stresses to great distances inland in channelized ice streams, The Cryosphere, 8, 2007-2029, https://doi.org/10.5194/tc-8-2007-2014, 2014.

Truffer, M., Harrison, W. D., and Echelmeyer, K. A., Glacier motion dominated by processes deep in underlying till, J. Glaciol., 46, 213-221, https://doi.org/10.3189/172756500781832909.6, 2000.

Tulaczyk, S., Kamb, W. B., and Engelhardt, H. F.: Basal mechanics of ice stream B, West Antarctica: 1. Till mechanics, J. Geophys. Res.-Sol. Ea., 105, 463-481, 2000.

Vaughan, D. G., Corr, H. F. J., Ferraccioli, F., Frearson, N., O'Hare, A., Mach, D., Holt, J. W., Blankenship, D. D., Morse, D. L., and Young, D. A.: New boundary conditions for the West Antarctic ice sheet: Subglacial topography beneath Pine Island Glacier, Geophys. Res. Lett., 33, L09501, https://doi.org/10.1029/2005GL025588, 2006.

Vaughan, D. G., Corr, H. F., Smith, A. M., Pritchard, H. D., and Shepherd, A.: Flow switching and water piracy between Rutford ice stream and Carlson inlet, West Antarctica, J. Glaciol., 54, 4148, https://doi.org/10.3189/002214308784409125, 2008.

Walder, J. S. and Fowler, A.: Channelized subglacial drainage over a deformable bed, J. Glaciol., 40, 3-15, 1994.

Weertman, J.: General theory of water flow at the base of a glacier or ice sheet, Rev. Geophys., 10, 287-333, 1972.

Wellner, J., Heroy, D., and Anderson, J.: The death mask of the Antarctic ice sheet: Comparison of glacial geomorphic features across the continental shelf, Geomorphology, 75, 157-171, https://doi.org/10.1016/j.geomorph.2005.05.015, 2006.

Wingham, D. J., Siegert, M. J., Shepherd, A., and Muir, A. S. Rapid discharge connects Antarctic subglacial lakes, Nature, 440, 1033-1036, 2006.

Zwally, H. J., Giovinetto, M., Beckley, B. A., and Saba, J. L.: Antarctic and Greenland drainage systems, GSFC Cryospheric Sciences Laboratory, available at: https://icesat4.gsfc.nasa.gov/ cryo_data/ant_grn_drainage_systems.php, 2012. 